腹膜再発巣切除後長期生存している胃平滑筋芽細胞腫の 1 例

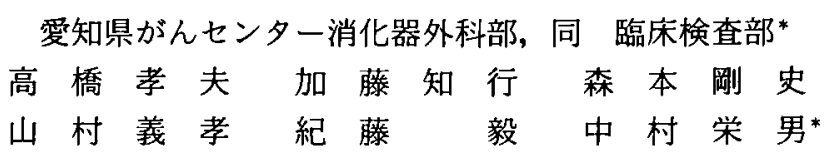

症例は初診時45歳の男性. 腹部腫瘤の診断で開腹術を施行. 胃前庭部大彎側に有茥性 胃外発育型腫瘍を認め, 胃局所切除にて腫湯を摘出した。摘出標本は大きさ $34 \times 30 \times 24$ $\mathrm{cm}$, 体重 $5,500 \mathrm{~g}$, 病理組織学的所見は胃平滑筋芽細胞腫であった. 初回手術から 6 年後 に直腸指診, 骨盤 CT で骨盤内腫瘤を認めた。 6 力月後の CT にて腫瘤の增大を認め, ダグラス窩再発を疑って開腹した. ダグラス窝，そして大網に 2 力所腫場を認め，それ ぞれを摘出した. 病理組織学的に胃平滑筋芽細胞腫の腹膜再発と診断された。再手術後 現在まで12年間再発の徵候は認めていない。

胃平滑筋芽細胞腫は比較的まれて悪性度の低い疾患とされるが, 原発巣切除 6 年後に 腹膜再発をきたし, 再発巣切除後長期間無再発生存中の 1 例を経験した. slow growing な腹膜再発は再切除できる症例があり，再発巣切除により長期生存も期待されると考え られた。

索引用語：胃平滑筋芽細胞腫, 腹膜再発

\section{はじめに}

胃平滑筋芽細胞腫は比較的まれな悪性度の低い腫瑒 である.1960年に Martin"が myoid tumorとして報 告したのが最初であり，その後1962年に Stout ${ }^{21}$ は胃筋 原性腫湯のうち核周囲に明るい空胞化した透明帯を伴 う特徵ある細胞形態を有するものをbizarre leiomyoblastoma と命名した. 本邦では吉田ら ${ }^{3 /}$ 1964年に報告して以来, 現在まで338例が報告されてい るが，そのうち腹膜再発をきたした例は13例にすぎな い. 今回, 原発巣切除 6 年後に腹膜再発をきたし, 再 発巣切除後長期間無再発生存中の 1 例を経験したので 文献的考察を加えて報告する.

\section{症例}

患者：初猃時45歳, 男性.

主訴：腹部膨満感。

既往歴：35歳時に尿路結石症, 44歳時に左鼠径へル ニア根治術施行.

既往歴：特記すべきことなし.

現病歴：1977年 4 月に腹部膨満感が出現. 徐々に増 強,さらに心窩部痛が出現したため, 1977年11月 1 日

1997年 3 月13日受付 1997年 6 月16日採用
当院受診した.

入院時現症：身長 $153 \mathrm{~cm}$, 体重 $54 \mathrm{~kg}$. 腹部は膨隆し, 腹壁の皮下静脈の怒脹を認めた。

入院時血液検查所見 : 白血球が $12,700 / \mathrm{mm}^{3}$ と高值 以外異常所見を認めず。

画像検查所見: 上部消化管造影検査, 超音波検査, 血管造影検查で腹腔内に要胞を有する巨大な腫瘍を認 めたが，確定診断はつかなかった。

経皮的腫瘍生検所見：暗血性り倠体を吸引儿, 細胞 診では macrophage が多数認められたが悪性細胞は 検出されなかった。尚, 細菌も検出されなかった。

以上より一部震胞性の巨大腹部腫瘤として1978年 1 月12日開腹術を施行した。

手術所見：腹腔内に血性腹水が少量貯留し, 血管が 怒脹した大網に稪われた㴶腫様の腫瘤が腹腔の大部分 を占めていた，大網を切離すると胃前庭部大彎側の胃 壁から発生した胃外発育型腫瘍であった。腹腔内の諸 臓器を圧排していたが肝, 横行結腸, 後腹膜など周辺 臓器への浸潤はなく, 腹腔内に転移巣も認めなかった。 胃局所切除にて腫瘍を摘出した。

摘出標本の肉眼所見：表面に不規則な山凸を認め， だるま型を呈していた，大きさ $34 \times 30 \times 24 \mathrm{~cm}$ ，重量 

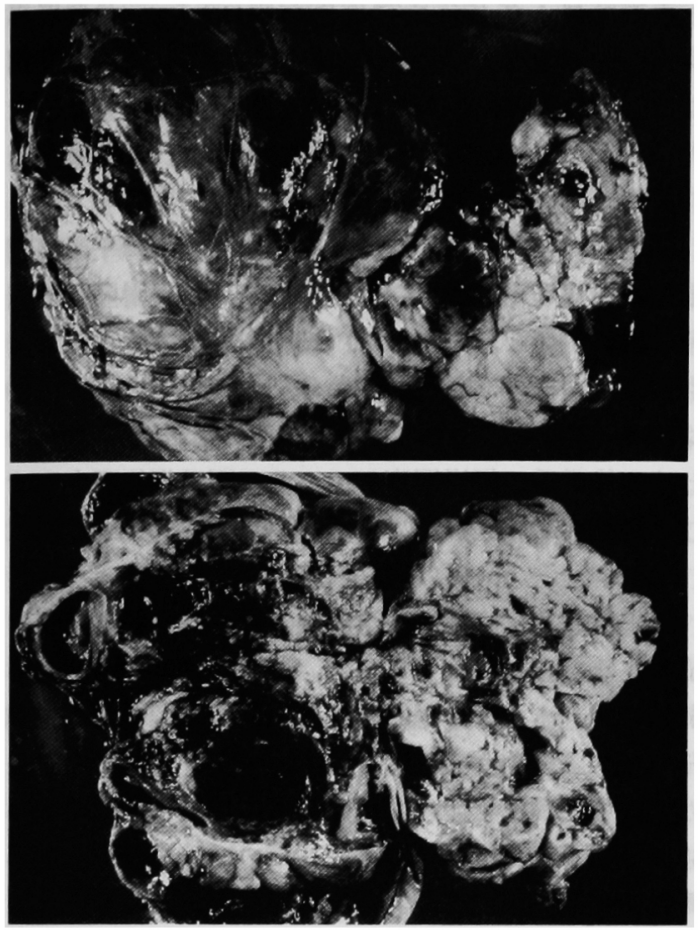

図 1 a, 摘出標本：大きさ $34 \times 30 \times 24 \mathrm{~cm}$, 重量 5,500 g で, 表面に不規則な山凸を認めた. b. 摘出標本割 面像：実質性な部分と蒷胞が多く混在した部分を認 めた。

$$
\frac{\mathrm{a}}{\mathrm{b}}
$$

$5,500 \mathrm{~g}$ であった。胃壁との付着面は直径 $2 \mathrm{~cm}$ であった (図 1a). 割面像は実質性で弾性軟, 黄褐色調の部分と 囊胞が多く混在し暗赤色調な部分とが認められた。賈 胞の内容は暗血性であった（図 1b)。

病理組織学的所見 (原発巣)：腫瘍細胞の核は主とし て楕円形ないし多角形で，多くの細胞では核の外周に 透明にぬけた胞体を認めた。 また胃との接着部には平 滑筋細胞を認めた． 細胞密度は比較的高く, 細胞異型 は中等度であったが核分裂像は認めなかった，免疫組 織学的にはデスミン, アクチン, ビメンチンは陽性, ケラチン, S-100は陰性であった。 以上より胃平滑筋芽 細胞腫と診断した（図 2a).

術後経過は良好で術後24日目に退院. 以後, 外来に て経過観察していた。

1984年 1 月（原発巣摘出 6 年後）直腸指診でダグラ ス窩に弾性軟な母指頭大の壁外腫瘤を触知し, 骨盤 CTにて骨盤内腫瘤を認め, 腹膜再発を疑い, 経過観察 した。同年 9 月の CT にて腫瘤の増大を認め, ダグラ

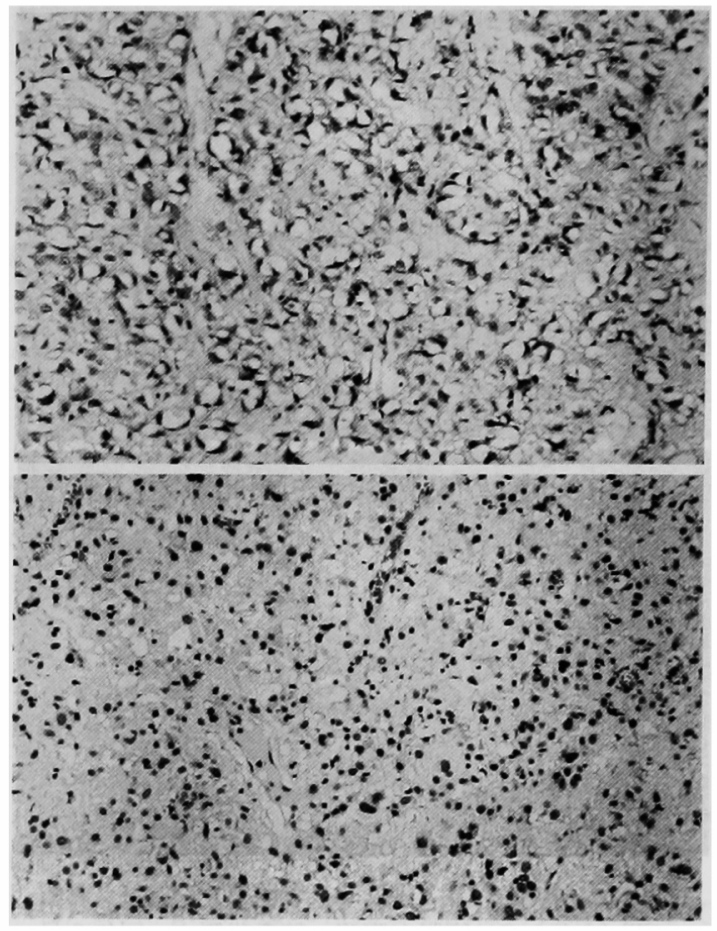

図 2 a. 病理組織所見 (原発栄) : 多くの細胞では核 の外周に透明にぬけた胞体を認めた（HE 染色, × 200). b. 病理組織所見 (腹膜再発巣)：初回手術時 と類似し，胃平滑筋芽細胞腫の像であった（HE 染 色, $\times 200)$ 。

$\frac{\mathrm{a}}{\mathrm{b}}$

ス窩腹膜再発と確診した。他臓器への浸潤や転移を認 めないので，手術目的で入院となった。

第 2 回入院時現症：身長 $153 \mathrm{~cm}$, 体重 $57 \mathrm{~kg}$, 眼結膜 に貧血, 黄疸は認めず。表在リンパ節は触知せず。直 腸指診にてダグラス窩に弾性軟な母指頭大の腫瘤を触 知した。

第 2 回入院時血液検査所見：軽度の白血球増多以外 末梢血, 生化学検査にて異常を認めず. 腫瘍マーカー は CEA 1.2ng/ml と正常であった.

骨盤 CT 検査：1984年 3 月の骨盤 CT では直腸の右 腹側, 精垔の背側に $1.5 \times 1.0 \mathrm{~cm}$ の境界明瞭な腫瘤を 認めた。同年 9 月の骨盤 CT で同部位に $2.5 \times 1.5 \mathrm{~cm}$ の腫瘤を認め, 同年 3 月の骨盤 CT と比較すると, 明 らかに増大していた（図 3a, 図3b). 腹部 CT では肝 転移など他に異常所見は認めなかった。

1984年10月15日胃平滑筋芽細胞腫のダグラス窩腹膜 再発の診断にて開腹術施行. 

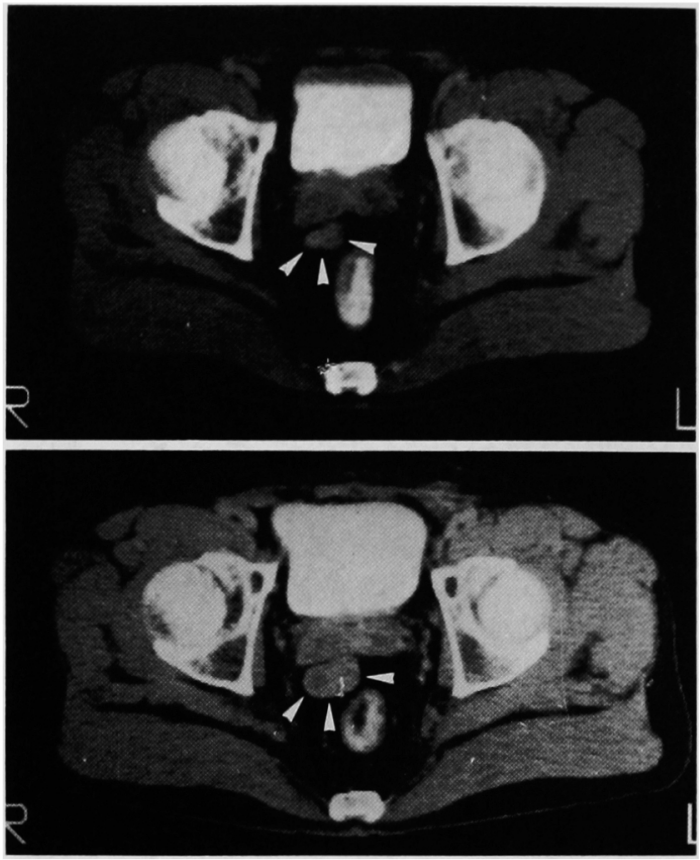

図３ａ，骨盤 CT（３月），b，骨盤 CT（９月）：骨盤 CT ( 9 月) では直腸右腹側, 精囊背側に, 同年 3 月 の骨盤 CT と比較すると, 明らかに増大した $2.5 \times$ $1.5 \mathrm{~cm}$ の境界明瞭な腫瘤を認めた。 $\frac{\mathrm{a}}{\mathrm{b}}$
手術所見：ダグラス窩やや右側に $2.5 \mathrm{~cm}$ 大の境界 明瞭, 表面平滑な腫瘍を認めた。直腸など他臓器浸潤 はなく，腫瘍摘出術を施行した．腹腔内を検索すると 大網に $3 \mathrm{~cm}$ 大の腫瘍を 2 力所に認め, それを摘出し た。他に病変は認めなかった。

病理組織学的所見 (腹膜転移巣)：前回の胃平滑筋芽 細胞腫の病理組織像と類似しておう, 胃平滑筋芽細胞 腫の腹膜再発と診断された。細胞密度, 細胞異型は前 回とほほ同様であったが, 核分裂像 (mitotic index) は200倍率50視野で 2 〜 であった（図 2b).

その後厳重に経過観察しているが再手術後現在まで 12年間再発の徴候は認めていない.

\section{考察}

胃平滑筋芽細胞腫は平滑筋腫と平滑筋肉腫の中間に 位置するものとされてきたが，現在では低悪性度の平 滑筋肉腫，または平滑筋肉腫の 1 亜型として位置付け られている報告が多い，松下ら ${ }^{4)}$ は胃平滑筋芽細胞腫 の10年生存率は予後の記載がある本邦報告例69例では $88.8 \%$ で予後良好と報告しているが，丸岡ら ${ }^{51}$ は本邦 報告304例の集計で27例（8.9\%）に他臟器直接浸潤ま たは転移を認め, 予後の記載がある転移14例の 2 年生 存率は $36 \%$ と, 転移をきたすと予後不良であったとし ている。

最近，転移例の報告は増加している，胃平滑筋芽細 胞腫は丸岡らの304例に新たに調べ得た34例を加えて

表 1 腹膜転移を伴った胃平滑筋芽細胞腫の本邦報告例

\begin{tabular}{|c|c|c|c|c|c|c|c|c|c|c|c|}
\hline 症例 & 報告者 & 報告年 & 年齢. 性 & 部位 & 発育型 & \begin{tabular}{|c|} 
最大径 \\
$(\mathrm{cm})$
\end{tabular} & $\begin{array}{c}\operatorname{mitosis} \times 200 \\
(\text { 個 } / \mathrm{HPF})\end{array}$ & $\begin{array}{c}\text { 腹膜転移以外の } \\
\text { 因子 }\end{array}$ & 腹膜転移時期 & $\begin{array}{l}\text { 腹膜転移 } \\
\text { 紧切除の } \\
\text { 有無 }\end{array}$ & $\begin{array}{l}\text { 初回手術 } \\
\text { 後の予後 }\end{array}$ \\
\hline 1 & 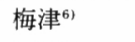 & 1977 & & & & & わずか & リンパ節, 肝 & 同時性 & 無 & \\
\hline 2 & 増田 ${ }^{7)}$ & 1979 & $13 \mathrm{M}$ & 胃上部 & & & & 肝, 肺 & 同時性 & 無 & 1 力月死 \\
\hline 3 & 大久保 ${ }^{81}$ & 1980 & $58 \mathrm{M}$ & 胃中部 & 䏴外 & 12 & 4 & 無 & 同時性 & 有 & 8 力月生 \\
\hline 4 & 菱沼9l & 1980 & $64 \mathrm{~F}$ & 胃上部 & 胃内外 & 20 & 陽性 & $\begin{array}{l}\text { 直接浸潤, } \\
\text { リンハ節 }\end{array}$ & 同時性 & 無 & 1 力月死 \\
\hline 5 & Kimura $^{10)}$ & 1981 & $29 \mathrm{~F}$ & 㫣上部 & 䏴外 & 7 & & 無 & 同時性 & 無 & 2 力月死 \\
\hline 6 & 木村"11 & 1984 & $76 \mathrm{M}$ & 胃上部 & 胃外 & 8 & & 無 & 同時性 & 無 & \\
\hline 7 & 稲垣 ${ }^{121}$ & 1986 & $22 \mathrm{M}$ & 胃下部 & 胃外 & 14 & & 無 & 同時性 & 有 & 7 力月生 \\
\hline 8 & 徳原 ${ }^{13)}$ & 1990 & $50 \mathrm{M}$ & 胃上中部 & 胃外 & 32 & $3 \sim 7$ & 肝 & 異時性 & 無 & 22 力月生 \\
\hline 9 & 丸岡5) & 1991 & $58 \mathrm{M}$ & 胃上部 & 胃内外 & 2.3 & 0 & 直接浸潤 & 同時性 & $\begin{array}{c}\text { 有 } \\
\text { (腫場残存) }\end{array}$ & 18 力月生 \\
\hline 10 & 佐溝 ${ }^{(4)}$ & 1993 & $50 \mathrm{M}$ & 胃中部 & 胃内外 & 19 & 75 & $\begin{array}{c}\text { 初回 : 直接浸潤, } \\
\text { 再之節 } \\
\text { 再朋 }\end{array}$ & $\begin{array}{l}\text { 異時性 } \\
\text { ( }{ }^{\circ} \text { 月) }\end{array}$ & 無 & 9 力月死 \\
\hline 11 & 山本 ${ }^{15)}$ & 1993 & $65 \mathrm{M}$ & 胃中部 & 胃内外 & 12 & 散見 & 無 & 異時性 ( 3 年) & (腫瘍残存) & 4 年死 \\
\hline 12 & 大橋(6) & 1994 & $71 \mathrm{M}$ & 胃中部 & 胃外 & 19 & 15 & 無 & ( 4 年, 8 年) & 有 & 10年生 \\
\hline 13 & 自験例 & 1996 & $51 \mathrm{M}$ & 胃中部 & 胃外 & 34 & 0 & 無 & 異時性 ( 6 年) & 有 & 16年生 \\
\hline
\end{tabular}


本邦報告例338例中，他葴器直接浸潤，または転移を認 める，いわゆる悪性胃平滑筋芽細胞腫は34例(10.1\%) であった。直接浸潤は $\times$ 例, 転移部位は重複している が, 肝15例，腹膜13例，リンパ節 8 例，局所 1 例，肺 1 例，骨 1 例，膵 1 例，鼠径部 1 例であり，肝転移と 腹膜転移が多かった。今回, 腹膜転移を認めた 13 (例) ${ }^{516)}$ を検討したが(表 1)，その特徵としては，90年 代に入って增加，年秢は13歳〜 76歳（平均50.6歳）と 幅広く，性別は男性 9 例女性 3 例（不明 1 例）と男性 に多い, 部位は冒上中部が11例と多く, 発育形式は全 て胃外型または胃内外型で胃内型は認めず, 腫場径は $2.3 \sim 34 \mathrm{~cm}$ (平均最大径 $16.3 \mathrm{~cm}$ ) で 8 例が $10 \mathrm{~cm}$ 以上で 大きいものが多いが胃内外型の $2.3 \mathrm{~cm}$ と小さいもの でも腹膜播種があるのが注目される，mitosisを認め ない，または少なくても再発している，転移因子は腹 膜転移以外にも肝転移などを重複している症例は 6 例 (46.1\%)と多く，それらの予後は不良である，などが 挙げられる。男性で胃上中部に発生した胃外型，また は胃内外型の大きな腫瘍では腹膜再発の危険性がある と考えられた。腹膜再発時期に関しては同時性 8 例 (62\%)，異時性 5 例（38\%）であり，同時性は予後が 悪い傾向にあった。これは他臓器転移合併例が多く, 腹膜播種転移巣の切除もできないものが多いので予後 不良になると思われた。北川らいは胃平滑筋芽細胞腫 肝転移の本邦報告例15例を検討しているが，中年男性 で胃上部に発生し，胃外性に大きく発育するのが特徵 であるとした。これは検討した腹膜転移例とほほ同様 な特徵で, 肝転移と腹腹転移とを区別する困子ははっ きりせず，上述した特徵をもつ症例は肝または，腹膜 転移の危険性を念頭に置くべきと思われた。

異時性腹膜再発 5 例のうち自験例を含め 3 例に再発 巣切除が施行され，うち2 例は根治的再切除が可能で あった。具体的には，1例は大橋らの症例16)で初回手術 後 4 年と 8 年目に腹膜再発し，それらをそれぞれ再切 除し, 初回手術後 10 年間長期生存中である。もう 1 例 は自験例であった。この 2 例は初回手術後長期間経過 して再発しており，このように slow growing に再発 した例は再発巣に対し，根治的に再切除ができる可能 性があり，再切除でき机ば長期生存を期待できること が示唆された。

腹膜再発の原因として, 北村ら $\left.{ }^{18}\right)$ は胃平滑筋肉腫術 後 6 年目の腹腔内再発症例で, 腹腔鏡検查生検時の腫 瘍細胞の散布が腹膜再発の原因と報告しているが, 自 験例でも手術操作中に腫瘍細胞を撒布したか，経皮的
腫晹生検施行時に腫瘍細胞を撒布した可能性もあると 考えられた。

悪性度の判定基準として一般的には核分裂像 (Mitotic index)が用いられる。しかし，HE 標本によ る核分裂像の判定には個人差が大きく, 核崩壊像や濃 縮像が分裂像と誤認されやすく，再現性がなかったと する報告 ${ }^{199}$ もあり，最近では Ki-67抗原, PCNA 染色, AgNOR 染色, DNA ploidy などが細胞増殖能をみる 手段として用いられ，悪性度の指標として有用である と報告されている ${ }^{102201211}$. また免疫特殊染色法では自 験例はデスミン,アクチンともに陽性であったが，平 滑筋由来の腫瘍が悪性化するとデスミン陰性, アクチ ン陽性となるとの報告もある ${ }^{22)}$. 胃平滑筋芽細胞腫は 全体的には low malignancyで予後はよい矮患とされ るが, 転移再発を認め, 予後不良な症例も存在する。 これらの鑑別法が検討課題である。

\section{結語}

（1）原発巣切除 6 年後に腹膜再発をきたし, 再発巣 切除後長期生存中の 1 例を経験した。

(2) slow growing に再発した例は再発巣に対して も根治術ができる可能性があり，根治術可能例は長期 生存を期待できることが示唆された。

尚, 本拝例は初问手術の状況について1980年に加藤らが 当時報告例では最大のものとして報告した ${ }^{23}$.

\section{文献}

1) Martin JF, Bazin P, Feroldi J, et al : Intramural myoid tumors of the stomach : Microscopic considerations on 6 cases. Ann Anat Path $5: 484$ 497, 1960

2) Stout AP: Bizarre smooth muscle tumor of the stomach. Cancer $15: 400-409,1962$

3）吉田明, 小針頼晴, 渡辺庄造: 胃平滑筋肉腫と思 われた 1 例について。 日医放線会誌 $24 ： 446-$ 447,1964

4）松下一之, 坂本昭雄, 碓井貞仁他：胃外有茎性発育 を示した胃平滑筋芽細胞腫の1例. 日消外会誌 $23: 75-79,1990$

5) 丸岡 彰, 千岩芳春, 三澤 正他：覀性胃平滑筋 芽細胞腫の 1 例. Gastroenterol Endosc $34: 1332$ $-1339,1992$

6）梅津佳英, 石岡国春, 佐藤 明他：胃の平滑筋芽細 胞腫の 1 例。 日臨細胞会誌 $16: 131-132,1977$

7) 增田幸久, 浅木 茂, 知念功雄他：急激な転㷌をと つた胃 leimyoblastoma $の 1$ 例. 日消病会誌 76 ： 2146.1979 
8）大久保史明, 松田正和, 池井 聡他：腹膜転移を伴 った悪性胃平滑筋芽細胞腫の 1 例. 消外 $3: 335$ $-341,1980$

9）菱沼正一, 大塚秋二郎，梅園 明他：冐に原発し た,いわゆる Malignant Leimyoblastoma と考え られる1症例について，日消病会誌 $77 ： 1175$, 1980

10) Kimura O, Kaibara N, Tamura $H$, et al: Comparative study on the nuclear DNA content of leiomyoma, leiomyoblastoma and leiomyosarcoma of the stomach and small intestine. Jpn J Surg 11: 428-432, 1981

11）木村彰彦, 谷田 理, 佐々下義夫他：平滑筋芽細胞 腫が疑われた俏粘膜下腫瘍の 1 例。日臨細胞会誌 $23: 723,1984$

12）稲垣 優, 成末允勇, 高橋 㑆他: 胃平滑筋芽細胞 腫の 2 例。広島医 $39: 1599,1986$

13）徳原太豪, 酒井克治, 木下博明他：術前診断しえた 巨大な胃平滑筋芽細胞腫の 1 例と本邦報告220例 の検討。日臨外医会誌 $51: 316-321,1990$

14）佐溝政広，中村 毅，多淵芳樹他：胃平滑筋芽細胞 腫の1例. 日消外会誌 $26: 864-868,1993$

15）山本誠己，田伏克惊，坂口雅宏他：特異な再発形態 をとった胃平滑筋芽細胞腫の 1 治験例.日臨外医 会誌 $54: 2086-2091,1993$
16）大橋龍一郎, 横山伸二, 喿田 啓他: 腹腔内再発病 巣の切除により10年間生存中の胃平滑筋芽細胞腫 の1例. 臨外 49:775-778, 1994

17）北川雄一, 田近徹也, 重岡伸樹地：同時性肝転移を きたした胃平滑筋芽細胞腫の 1 例. 日臨外医会誌 $57: 384-388,1996$

18）北村正次, 荒井邦佳, 宮下 蒠他：術後 6 年目に腹 腔内再発をおした壁外性発育型の胃平滑筋肉腫の 1 例. 日消外会誌 23:2793-2797, 1990

19) Silverberg SG : Reproducibility of the mitosis count in the histologic diagnosis of smooth muscle tumors of the uterus. Hum Pathol $7: 451$ $-4.54,1976$

20）松田圭二, 渡辺英伸, 西倉 健他：新しい視点から みた青筋原性腫瘍の病理。胃と腸 30：11091124,1995

21）二階堂孝，山田哲也，下田忠和他：胃原発平滑筋肉 腫における悪性度診断の客観的指標の検索．胃と 腸 $30: 1125-1132,1995$

22) Evans DJ, Lampert IA, Jacobs $M$ : Intermediate filaments in smooth muscle tumors.J Clin Pathol 36:57-61, 1983

23）加藤知行, 紀藤 毅, 山田栄吉他：胃外性に発育し た巨大な胃の leimyoblastoma $の 1$ 例. 癌の臨 $26: 87-91,1980$ 


\title{
A LONG SURVIVING CASE OF LEIOMYOBLASTOMA OF THE STOMACH AFTER RESECTION OF RECURRENT FOCI IN THE RETROPERITONEUM
}

\author{
Takao TAKAHASHI, Tomoyuki KATO, Takeshi MORIMOTO, Yoshitaka YAMAMURA, \\ Tsuyoshi KITO and Shigeo NAKAMURA* \\ Department of Gastrointestinal Surgery and Clinical Laboratory, Aichi Cancer Center Hospital
}

A 45-year-old man at time of initial visit had undergone a laparotomy with a diagnosis of having an abdominal tumor, when a pedunculated tumor of extraluminal growth was found out at the greater curvature of antrum of the stomach. partial excision of the stomach including the tumor was carried out. The excised tumor was $34 \times 30 \times 24 \mathrm{~cm}$ in size and 5,500 $\mathrm{g}$ in weight. Histopathologically it was leiomyoblastoma of the stomach. Six years after the initial operation, a digital examination of the rectum and pelvic CT revealed an intrapelvic tumor. Then 6 months later, an enlargement of the tumor was confirmed on CT. A laparotomy was conducted with a suspiction of a recurrence in the Douglas pouch, and two tumors located in the Douglas pouch and greater omentum were found and extirpated. Histopathologically they was peritoneal recurrence of the leiomyoblastoma of the stomach. There has been no sign of recurrence as of 12 years after the reoperation.

It has been believed that gastric leiomyoblastoma is a relatively rare entity of low grade of malignancy. We encountered a patient with the disease who experienced a peritoneal recurrence 6 years after the initial operatin, and is still having a long recurrence-free normal life after the removal of the recurrent lesions. It is thought that slowly growing peritoneal recurrence of gastric leiomyoblastoma can be resected in some cases and a long survival can be also expected after removal of the recurrent foci. 